\title{
Batrachochytrium dendrobatidis infection patterns among Panamanian amphibian species, habitats and elevations during epizootic and enzootic stages
}

\author{
Forrest M. R. Brem ${ }^{1,2, *}$, Karen R. Lips ${ }^{1}$ \\ ${ }^{1}$ Department of Zoology, Southern Illinois University, Carbondale, Illinois 62901-6501, USA \\ ${ }^{2}$ Present address: Department of Biology, University of Memphis, Memphis, Tennessee 38152, USA
}

\begin{abstract}
The pathogenic fungus Batrachochytrium dendrobatidis $(B d)$ has caused declines of many amphibian populations, yet the full course of the epizootic has rarely been observed in wild populations. We determined effects of elevation, habitat, and aquatic index (AI) on prevalence of infection among Panamanian amphibians sampled along 2 elevational transects. Amphibian populations on the Santa Fé transect (SFT) had declined in 2002, while those on the El Copé transect (ECT) were healthy until September 2004. In 2004 we sampled $B d$ along both transects, surveying the SFT $2 \mathrm{yr}$ after decline, and surveying the ECT 4 mo prior to the arrival of $B d$, during the epizootic, and 2 mo later. Overall prevalence of $B d$ along the ECT increased from 0.0 (95\% CI $0.00-0.0003$ ) to 0.51 (95\% CI 0.48-0.55) over a 3 mo period, accompanied by significant decreases in amphibian abundance and species richness in all habitats. Prevalence of infection on the ECT was highest along riparian transects and at higher elevations, but not among levels of AI. Prevalence of infection on the SFT was highest in pool transects, and at higher elevations, but not among levels of AI. Riparian amphibian abundance and species richness also declined at SFT following detection of $B d$ in 2002. Variation among species, microenvironmental conditions, and the length of coexistence with $B d$ may contribute to observed differences in prevalence of $B d$ and in population response.
\end{abstract}

KEY WORDS: Batrachochytrium dendrobatidis · Amphibians - Population · Habitat - Elevation · Panama

Resale or republication not permitted without written consent of the publisher

\section{INTRODUCTION}

A growing number of emerging infectious diseases are contributing to the global loss of biodiversity (National Academy of Science 2001). Determining whether a host-pathogen relationship is new or old is the first step in understanding host-pathogen dynamics and designing effective conservation measures. Stable or coevolved host-pathogen systems typically involve enzootic pathogens, which are characterized by generally avirulent infections or a very low number of new infections per unit time (incidence), and a relatively constant proportion of infected individuals (prevalence). With enzootic pathogens, host extinction risk can be minimized in several ways: density of infected hosts is generally low, infection may be aviru- lent, hosts may have immunity or resistance (Swinton et al. 2002), host behavior may reduce exposure to disease (Rowley \& Alford 2007), or the pathogen may have low transmissibility (Anderson \& May 1992).

Host population extinctions can occur when novel pathogens are introduced into naive populations, and are characterized by an exponential increase in prevalence of infection from very low to very high levels in a short time period. Pathogens that drive host populations to extinction often have mechanisms that increase the efficiency at which the pathogen spreads, and include high transmissibility, density-independent transmission, and the presence of biotic or abiotic reservoirs (de Castro \& Bolker 2005). Environmental changes may cause some enzootic pathogens to become epizootic by causing them to expand their dis- 
tribution into new areas, alter host behavior, or affect transmission rates (Gubler 1998, Harvell et al. 2002, Pascual et al. 2008).

Probability of host extinction is strongly influenced by the mode of transmission. Extinction is most likely when transmission is frequency-dependent because even at low densities behaviors such as territoriality, mating, habitat preferences, and other aggregative behaviors can facilitate transmission by maintaining high contact rates among remaining individuals (e.g. de Castro \& Bolker 2005). Theoretically, densitydependent transmission could cause host population extinctions if transmissibility were extremely high (Anderson \& May 1992). Host extinction usually does not occur under density-dependent transmission because at low host densities host-pathogen contact rates are decreased, leading to fade-out or extinction of the pathogen (Anderson \& May 1981).

Batrachochytrium dendrobatidis $(B d)$, is a fungal pathogen of amphibians that causes chytridiomycosis, an emerging infectious disease that has been studied in amphibians at both the enzootic (e.g. Retallick et al. 2004, Woodhams \& Alford 2005, Kriger \& Hero 2006, Puschendorf et al. 2006) and epizootic (Lips et al. 2006, Rachowicz et al. 2006) stages. During $B d$ epizootics in Central America, this pathogen can cause $~ 80 \%$ reductions in amphibian abundance, and losses of $\sim 50 \%$ of species richness in $<5$ mo (Lips et al. 2006). It is generally accepted (Daszak et al. 2000, Skerratt et al. 2007 ) that $B d$ is an exotic pathogen that has been introduced around the globe (Morehouse et al. 2003); thus, sites where $B d$ is now enzootic likely experienced historic, unobserved epizootics (e.g. Pounds et al. 1997, Puschendorf et al. 2006).

Chytridiomycosis, the disease caused by $B d$, is assumed to follow typical disease progression in which incidence and the density of infected and susceptible individuals varies over the course of an epizootic. Initial high density of susceptible individuals and low $B d$ prevalence is followed by exponential increase in $B d$ prevalence and high host mortality. Once $B d$ becomes enzootic the density of susceptible individuals is very low, and environmental and ecological interactions may regulate amphibian populations directly, or may affect them indirectly by influencing the growth and survival of $B d$. For example, warmer or drier habitats (Ron 2005) are less favorable to survival of $B d$, and may reduce transmissibility, infection prevalence, and pathogenicity of $B d$. Temperature and moisture influence $B d$ survival in lab cultures (Piotrowski et al. 2004), severity of infection in laboratory challenges (Woodhams et al. 2003), and prevalence of infection in nature (Retallick et al. 2004, Woodhams \& Alford 2005, Kriger $\&$ Hero 2007). Additionally, pathogenicity of $B d$ may vary among species of amphibians (Nichols et al. 2001,
Davidson et al. 2003, Daszak et al. 2004, Lips et al. 2006). Where $B d$ is enzootic, amphibian communities are likely comprised of individuals in which $B d$ has low pathogenicity or that have avoided becoming infected by $B d$ (e.g. Harris et al. 2006, Rachowicz et al. 2006).

Our objectives were to compare prevalence of $B d$ infection at pre-epizootic, epizootic, and enzootic stages of $B d$ occurrence from multiple habitats along 2 elevational transects in central Panama. Based on disease theory and previous patterns of population decline at other sites (e.g. Lips et al. 2003b), we predicted that the highest prevalence of $B d$ infection would be found during the epizootic stage, in upland (>500 $\mathrm{m}$ ) riparian areas, and in those species with the greatest use of aquatic habitats over their lifetime. Understanding differences in prevalence among habitats and species of different ecologies may help determine how we manage infected populations and prevent future spread.

\section{MATERIALS AND METHODS}

Study sites. We established 2 parallel elevational transects, each oriented on a south-north axis along 2 paved roads that began at the intersection with the Interamerican Highway (Fig. 1) and which terminated within a national park located on the Continental Divide. Each transect was named after the largest town nearest the 2 contiguous national parks at the upper terminus of each transect. The 2 parks are ecologically similar and represent 2 points (epizootic, enzootic) along a chronosequence of pathogen invasion. Amphibian surveys began at both sites in 1998; Santa Fé experienced a die-off in 2002, and amphibians at El Copé experienced a die-off in 2004. We invested the greatest amount of survey effort at El Copé where research facilities were available, and made short trips to Santa Fé yearly to evaluate the status of amphibians at that site. We report results from Santa Fé for comparative purposes, although sample sizes prevented complete statistical analyses in many cases.

We used visual encounter surveys (VES) (Lips et al. 2001) to quantify amphibian abundance and species richness and to obtain skin swabs to test for $B d$ in amphibians along 13 sub-transects located along the El Copé transect (ECT), and conducted identical sampling of frogs and fungus along 7 sub-transects located along the Santa Fé transect (SFT). For every individual amphibian we collected the same morphological and ecological data: species, snout-vent length (SVL), mass, location along the transect, perch height, and perch substrate. We determined GPS coordinates and elevation at the midpoint of each transect with a GPS 12 Personal Navigator $\left(\right.$ Garmin $^{\mathrm{TM}}$ ), or extrapo- 


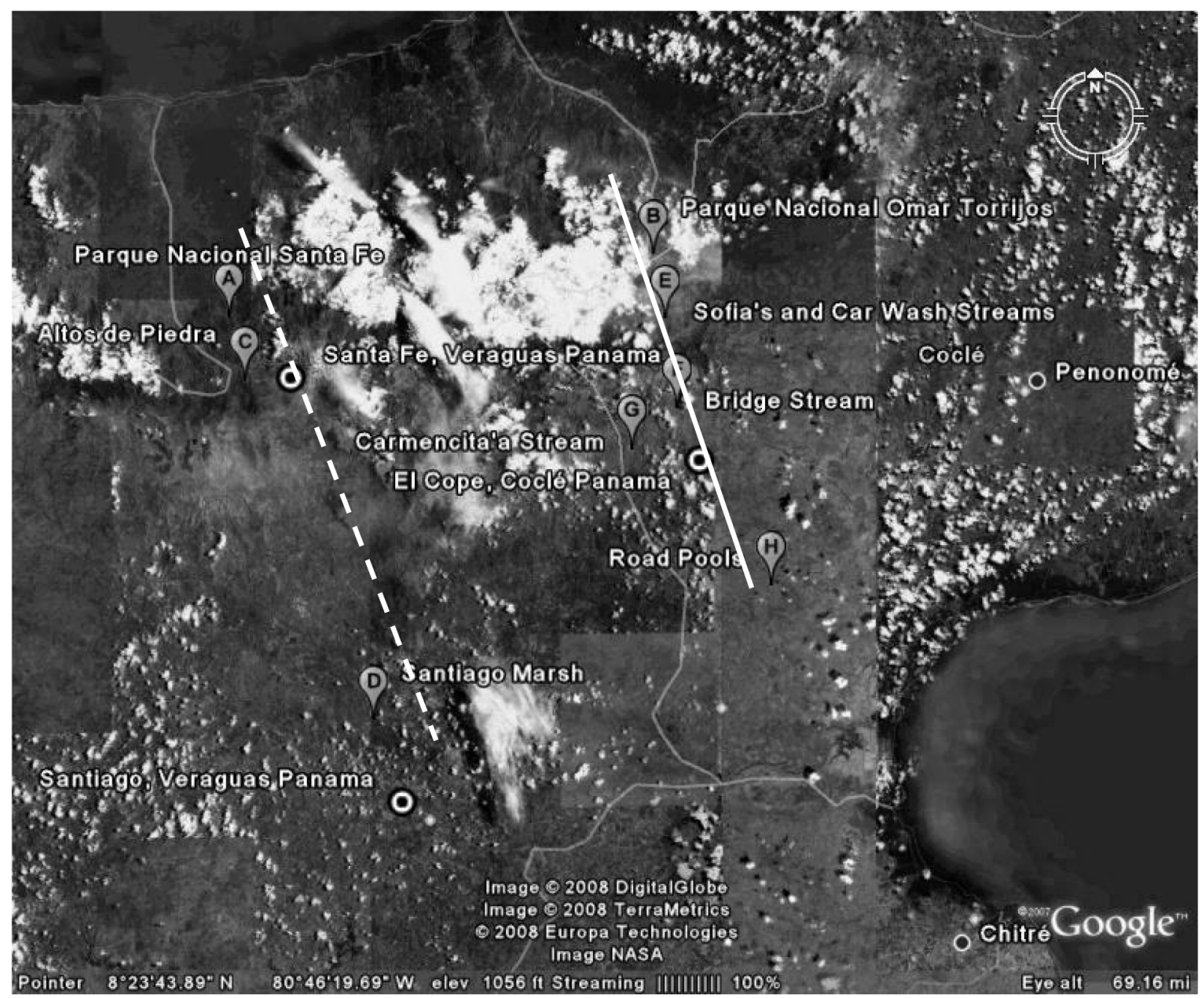

Fig. 1. Location of Santa Fé (dashed line) and El Copé (solid line) elevational transects and focal sampling areas in Panama. A: Parque Nacional Santa Fé (PNSF): Eagle Arch Stream, Quebrada Tigre, Quebrada Mula. B: Parque Nacional Division Omar Torrijos (PNOT) transects > 500 m: Quebrada Guabal, Quebrada Silenciosa, Quebrada Cascada, Loop Stream, Main Trail, Loop Trail, Verrugosa Trail, Verrugosa Pond. C: Altos de Piedra: Altos de Piedra Road, Escuela Altos de Piedra, Altos de Piedra Swamp. D: Santiago Marsh. El Copé streams < 500 m. E: Sofia's Stream and Car Wash Stream. F: Bridge Stream. G: Carmencita's Stream. H: Road Pools

lated the position from reference points taken along the road.

El Copé, Coclé Province, Panama (ECT): The ECT was $\sim 25 \mathrm{~km}$ in length, and began at $80 \mathrm{~m}$ elevation at a site $5 \mathrm{~km}$ north of the intersection of the El Copé road and the Interamerican Highway $\left(8^{\circ} 34.246^{\prime} \mathrm{N}\right.$, $\left.80^{\circ} 35.217^{\prime} \mathrm{W}\right)$. The ECT passed through the town of El Copé, Coclé Province, Panama at approximately $300 \mathrm{~m}$ elevation, and terminated on the Continental Divide at $760 \mathrm{~m}$ elevation in Parque Nacional Division General Omar Torríjos Herrera (PNOT; $8^{\circ} 40^{\prime} \mathrm{N}$, $80^{\circ} 37.62^{\prime} \mathrm{W}$ ). PNOT covers 25275 ha over an elevational range of 500 to $1300 \mathrm{~m}$ and is situated along the
Continental Divide of the Cordillera Central. The ECT passed through a variety of habitats from lowland dry forest at lower elevations to tropical moist forest at the higher elevations of PNOT (Holdridge 1967), which provided environmental variation to compare patterns of $B d$ infection prevalence among habitats. We surveyed transects in 3 watersheds: (1) the Río Grande (Carmencita's Stream) and (2) the Río Colorado (Car Wash, Sofia's, and Bridge Streams) which merge below the town of El Copé and flow into the Pacific Ocean, and (3) the Río Guabal (all 4 streams within PNOT), which drains northward into the Atlantic Ocean. 
We had been monitoring the amphibian fauna of PNOT since 1998; thus, patterns of habitat use and relative abundance were known for most species. We conducted weekly nocturnal and diurnal VES on four $200 \mathrm{~m}$ riparian transects and three $400 \mathrm{~m}$ terrestrial transects within the park for 3 to 4 mo during the early rainy season (May to August) between 1998 and 2003. Between September 2003 and April 2005 we monitored these 7 transects year-round but reduced monitoring frequency to 1 diurnal and 1 nocturnal VES on each of the 4 riparian sub-transects per month, and 1 nocturnal VES on each of the 3 terrestrial sub-transects per month. In May 2004 we established 4 additional riparian sub-transects and 1 additional terrestrial subtransect outside the park at elevations $<500 \mathrm{~m}$ where we surveyed amphibians in May 2004 and again in November to December 2004.

In January 2004, we initiated non-destructive sampling of amphibians for $B d$ infection within PNOT by swabbing wild amphibians following a protocol modified from Hyatt et al. (2007) and had Pisces Molecular Lab analyze swabs for $B d$ using a conventional PCR assay (Annis et al. 2004). Between January 2004 and January 2005 we collected swab samples bi-monthly from 2991 amphibians of 62 species on the 13 sub-transects along the ECT during routine VES. Between October 2004 and January 2005 a mass mortality event occurred at PNOT, during which we found 442 dead or dying frogs and observed subsequent population declines (Lips et al. 2006). We microscopically examined $(400 \times)$ unstained, wet-mounted, formalin fixed, epidermal tissue from the hands and feet of 318 of the 442 individuals for the presence of $B d$ thalli and sporangia (Appendix 1). The PCR assay was not commercially available until 2003, so to determine whether $B d$ was present at ECT prior to 2004 we used histology to examine museum specimens for the presence of $B d$ (Puschendorf \& Bolaños 2006). We examined 146 preserved museum vouchers collected from this site between 2000 and 2003 (Lips et al. 2006); these have been deposited in the Southern Illinois University Wet Vertebrate Collection (Appendix 1).

Santa Fé, Veraguas Province, Panama (SFT): Parallel to the ECT and located approximately $50 \mathrm{~km}$ to the west, the SFT was $\sim 60 \mathrm{~km}$ in length, and began $5 \mathrm{~km}$ north of the town of Santiago, Veraguas, Panama (Fig. 1; $8^{\circ} 30.836^{\prime} \mathrm{N}, 81^{\circ} 6.862^{\prime} \mathrm{W}$ ). The SFT encompassed a similar range of elevations and habitats as the ECT, passing through the town of Santa Fé and terminating within Parque Nacional Santa Fé (PNSF; $\left.8^{\circ} 31.907^{\prime} \mathrm{N}, 81^{\circ} 8.980^{\prime} \mathrm{W}\right)$.

We have been visiting Santa Fé annually since 1998 as part of an ongoing study into the patterns of amphibian declines in Latin America. Because of the lack of facilities and difficult access, sampling effort at PNSF was not as intensive as that at PNOT, and was designed only to detect major changes in amphibian abundance. In 1998 and 1999, we surveyed diurnal stream transects for 1 brightly colored indicator species (Atelopus varius) over a few days. Between 2000 and 2003, we continued those diurnal surveys, but added nocturnal surveys along one $3 \mathrm{~km}$ terrestrial transect, and along three $400 \mathrm{~m}$ riparian transects. We calculated survey effort (captures $\mathrm{m}^{-1} \mathrm{p}^{-1}: \mathrm{p}=$ person) for the 2 transects surveyed continuously between 1998 and 2004 .

To determine whether $B d$ had been present at SFT prior to the observed die-off in 2002, we used histology (Puschendorf \& Bolaños 2006) to examine 87 preserved museum vouchers (Appendix 1) from SIUC (12 individuals collected in 2002 and 13 collected in 2003), and from the University of Michigan Museum of Vertebrate Zoology (62 individuals collected in 1978). In 2004, after the PCR assay was commercially available we estimated prevalence of $B d$ by swabbing 183 amphibians on 7 sub-transects along the SFT.

Statistical analyses. We used repeated measures trend analysis (Sokal \& Rohlf 1995) to test the hypotheses that $B d$ infection prevalence would increase and that relative abundance of amphibians would decrease, over the course of a chytridiomycosis epizootic. We analyzed trends in monthly averages for these 2 variables for amphibians sampled bimonthly between January 2004 and February 2005 within PNOT. This analysis was not possible for any other site because sampling was conducted at uneven intervals, too infrequently, or without replication. However, we summarize amphibian abundance and species richness for each site (see Table 4). We calculated $B d$ infection prevalence and $95 \%$ Clopper-Pearson binomial confidence intervals (CI) for all species sampled along each gradient.

We then performed logistic regression analysis (Sokal \& Rohlf 1995) on data from each of the 2 transects to evaluate the effects of elevation, aquatic index (AI), and habitat on the prevalence of infection. For each capture we categorized elevation as high $(>500 \mathrm{~m})$ or low $(<500 \mathrm{~m})$, habitat as either terrestrial, pool/puddle, or riparian, and AI as a continuous variable between one (completely riparian) and 3 (completely terrestrial) that described the average level of aquatic habitat use over a species' lifetime (see Lips et al. 2003b). Main-effect variables were excluded from the model if they were not significant predictors of the prevalence of infection (Hosmer \& Lemeshow 2000). Interactions among variables were then individually included in the model to test for significant pair-wise interactions. Finally, we tested for overall model significance (chi-square test), and fit of observed data to predicted values (goodness-of-fit, Hosmer \& Lemeshow 2000). 


\section{RESULTS}

\section{Santa Fé transect}

Pre-epizootic

All 62 museum specimens collected at PNSF in 1978 were negative for $B d(0.00,95 \%$ CI $0.00-0.06)$. In July 1998 no abnormalities associated with either $B d$ or iridovirus were found in histological examinations of the 30 tadpoles (4 species), and 48 adult (15 species) amphibians from Santa Fé (D. E. Green pers. comm.). In July 2001 we examined 34 tadpoles belonging to 4 species and found none with obvious losses of mouthparts, although none were examined histologically. All 12 amphibians collected in 2002 were negative for $B d$ (0.00, 95\% CI 0.00-0.26). Bd likely invaded PNSF in December 2002, when it was drawn to our attention by E. Toríbio, a local naturalist, who sent K. R. Lips an email describing 16 dead Atelopus varius from a stream adjacent to the Quebrada Tigre transect. Amphibian species richness showed no major changes until 2002, although between 1998 and 2004 the density of amphibians declined significantly on the 2 main survey transects $\left(\mathrm{R}^{2}=0.6967, y=-0.0071 x+14.167\right.$; Table 1).

\section{Epizootic}

In 2003 we made 3 separate trips to PNSF over a 4 mo period and ran the same 2 diurnal and 1 nocturnal transects; amphibian captures declined from 50 individuals in July, to 11 in August and 14 in October. In July 2003, we noted a major reduction in overall amphibian abundance. We returned in August and found 1 dead Pristimantis museosus and 1 dying Ecnomiohyla miliaria that were both heavily infected with $B d$. At this time, tadpoles of Lithobates warszewitschii were still numerous, but 11 of 14 individuals

Table 1. Declines in density of Santa Fé amphibians (captures $\mathrm{m}^{-1} \mathrm{p}^{-1}$ ) on 2 primary transects. Declines are first evident by 2002

\begin{tabular}{|lcccc|}
\hline \multirow{2}{*}{ Year } & \multicolumn{2}{c}{ Eagle Arch } & \multicolumn{2}{c|}{ Quebrada Tigre } \\
& A.M. & P.M. & A.M. & P.M. \\
\hline 1998 & 0.0285 & - & - & - \\
1999 & 0.0240 & 0.0294 & 0.0060 & - \\
2000 & 0.0200 & 0.0378 & 0.0189 & 0.2150 \\
2001 & 0.0170 & 0.0383 & 0.0190 & - \\
2002 & 0.0196 & 0.0267 & 0.0117 & 0.2000 \\
2003 & 0.0014 & 0.0082 & 0.0040 & 0 \\
2004 & 0.0008 & 0 & 0 & 0.0150 \\
Pearson product- & -0.9228 & -0.9602 & -0.5506 & -0.8554 \\
moment correlation & & & & \\
\hline
\end{tabular}

examined had some degree of mouthpart loss. We found only one other species of tadpole (Hyloscirtus palmeri), and it too was missing mouthparts. At least 5 species were missing in 2003 that had been regularly encountered before: Craugastor punctariolus, Hylomantis lemur, Cochranella albomaculata, Gastrotheca cornuta, and Silverstonei flotator. In the case of Atelopus varius and $H$. palmeri, the last individuals found were all females. Of the amphibians collected in 2003, 10 of 13 adults were positive for $B d$ (prevalence $=0.77$; $95 \% \mathrm{CI}=0.46-0.95)$, and $B d$ prevalence in tadpoles was $0.20(0.04-0.28)$.

\section{Enzootic}

In July 2004, we encountered only 13(31\%) of the 42 resident species (Table 2 ); only 2 species ( 6 adults and 18 tadpoles) were found in riparian habitats. Most captures $(86 \%)$ and species were found in either terrestrial or pool/puddle habitats. Of the 13 species sampled along the SFT in 2004, individuals of 4 species with low sample sizes (Cochranella albomaculata, Dendrobates auratus, Craugastor crassidigitus, and Leptodactylus mystacinus) were negative for $B d$. Populations of the 9 more abundant species $(\mathrm{N} \geq 4)$ were all infected with $B d$. Only D. microcephalus, Lithobates pipiens sp. 'E', L. warszewitschii, and Smilisca phaeota had adequate sample sizes $(\mathrm{N} \geq 20$ ) to estimate the prevalence of infection and obtain reasonable $95 \%$ CI. At elevations $>500 \mathrm{~m}$, the most abundant species were L. pipiens sp. ' $\mathrm{E}^{\prime}(21 \%$ of captures; 0.74 prevalence, $95 \% \mathrm{CI}=$ $0.57-0.87), S$. phaeota $(18 \% ; 0.12,0.03-0.28)$, and $L$. warszewitschii $(12 \%$; 0.23, 0.08-0.45). At elevations $<500 \mathrm{~m}$, all captures were of D. microcephalus (33\%; $0.21,0.12-0.24$ ) found in the Santiago Marsh sub-transect. In total, $B d$ infected $69 \%$ of amphibians sampled along the SFT (Table 3).

Both habitat and elevation — but not AI — influenced $B d$ prevalence on the SFT (Table 4) and there were no significant interactions. The overall model was highly significant (Table 4), and the Hosmer and Lemeshow (2000) goodness-of-fit test $\left(\chi^{2}=0.6651, \mathrm{df}=5\right.$, $\mathrm{p}=0.9848$ ) indicated adequate model fit. Coefficient estimates indicated that, during the enzootic stage, $B d$ infection prevalence was highest in terrestrial habitats, followed by pool and puddle habitats, and lowest in riparian habitats, which differed from the pattern of infection described for the epizootic at PNOT. Amphibians found at higher elevations were more likely to be infected than those at 
Table 2. Batrachochytrium dendrobatidis among amphibian species. Infection prevalence (95\% Clopper-Pearson binomial confidence intervals) for each species captured along Santa Fé transect, July 2004. N: Total captures

\begin{tabular}{|lcc|}
\hline Species & N & Prevalence \\
\hline Ollotis conifera & 1 & $1.00(0.03-1.00)$ \\
Rhinella marinus & 9 & $0.11(0.00-0.48)$ \\
Cochranella albomaculata & 2 & $0.00(0.00-0.84)$ \\
Dendrobates auratus & 2 & $0.00(0.00-0.84)$ \\
Agalychnis callidryas & 6 & $0.83(0.36-0.99)$ \\
Dendropsophus microcephalus & 61 & $0.21(0.12-0.24)$ \\
Hyloscirtus palmeri & 4 & $0.50(0.07-0.93)$ \\
Smilisca phaeota & 33 & $0.12(0.03-0.28)$ \\
Craugastor crassidigitus & 3 & $0.00(0.00-0.71)$ \\
Pristimantis diastema & 3 & $0.67(0.09-0.99)$ \\
Leptodactylus mystacinus & 2 & $0.00(0.00-0.84)$ \\
Lithobates pipiens sp. 'E' & 38 & $0.74(0.57-0.87)$ \\
Lithobates warszewitschii & 22 & $0.23(0.08-0.45)$ \\
\hline
\end{tabular}

lower elevations (Table 4), although sampling effort was biased towards high elevation sites, which may have affected the results.

Odds-ratio estimates were $0.530 \quad(95 \% \quad \mathrm{CI}=$ 0.23-0.12) for pool/puddle versus terrestrial habitats and 0.21 (0.06-0.68) for stream versus terrestrial habitats, which means that amphibians found in terrestrial habitats were twice as likely to be infected as those in pool/puddle habitats, while amphibians captured in pool/puddle habitats were 5 times more likely to be infected than riparian captures (Table 4). The odds-ratio estimate for elevation was 3.15 (1.33-7.46), indicating that amphibians captured at higher elevations were 3 times more likely to have been infected than amphibians from lower elevations (Table 4).

\section{El Copé transect}

Pre-epizootic

Amphibian richness and abundance was high prior to the first detection of $B d$; this was followed by a rapid and large-scale reduction in abundance and richness immediately following the first positive test for $B d$ in September 2004 (Lips et al. 2006). Between January and September 2004 the average annual densities of pre-epizootic riparian amphibian populations were 0.10 to 0.25 captures $\mathrm{m}^{-1} \mathrm{p}^{-1}$ (Fig. 2a), which was comparable to historic levels (e.g. Lips et al. 2006). All 146 individual amphibians collected between 1998 and 2004 prior to observed die-offs in 2004 and examined using histology were negative for $B d$ (Appendix 1), as were the 1420 swabs collected from live frogs (prevalence $=0.00,95 \% \mathrm{CI}=0-0.003$; Lips et al. 2006).

Table 3. Batrachochytrium dendrobatidis $(B d)$. Locations of sub-transects (elevation), numbers of individuals and species swabbed; and prevalence of $B d$ infection (95\% Clopper-Pearson binomial confidence intervals) along Santa Fé (July 2004$)$ and El Copé transects (November to December 2004)

\begin{tabular}{|c|c|c|c|}
\hline Transects & GPS location & $\begin{array}{l}\text { No. individuals } \\
\text { (No. species) }\end{array}$ & $\begin{array}{l}\text { Prevalence } \\
(95 \% \text { CI })\end{array}$ \\
\hline \multicolumn{4}{|l|}{ Santa Fé sub-transects } \\
\hline Santiago Marsh (80 m) & $8^{\circ} 11.02^{\prime} \mathrm{N}, 80^{\circ} 57.164^{\prime} \mathrm{W}$ & $58(1)$ & $0.17(0.09-0.29)$ \\
\hline Eagle Arch Stream (600 m) & $8^{\circ} 32.542^{\prime} \mathrm{N}, 81^{\circ} 04.992^{\prime} \mathrm{W}$ & $3(2)$ & $0.00(0.00-0.70)$ \\
\hline Quebrada Tigre (670 m) & $8^{\circ} 33.753^{\prime} \mathrm{N}, 81^{\circ} 03.115^{\prime} \mathrm{W}$ & $6(4)$ & $0.17(0.00-0.64)$ \\
\hline Quebrada Mula (730 m) & $8^{\circ} 34.243^{\prime} \mathrm{N}, 81^{\circ} 24.98^{\prime} \mathrm{W}$ & $22(4)$ & $0.27(0.11-0.50)$ \\
\hline Alto Piedra School (850 m) & $8^{\circ} 30.836^{\prime} \mathrm{N}, 81^{\circ} 06.862^{\prime} \mathrm{W}$ & $22(4)$ & $0.00(0.00-0.15)$ \\
\hline Alto Piedra Road (870 m) & $8^{\circ} 30.836^{\prime} \mathrm{N}, 81^{\circ} 06.862^{\prime} \mathrm{W}$ & $28(7)$ & $0.75(0.55-0.89)$ \\
\hline Alto Piedra Swamp (880 m) & $8^{\circ} 30.836^{\prime} \mathrm{N}, 81^{\circ} 06.862^{\prime} \mathrm{W}$ & $27(4)$ & $0.85(0.66-0.96)$ \\
\hline Road Pools $(80 \mathrm{~m})$ & $8^{\circ} 34.246^{\prime} \mathrm{N}, 80^{\circ} 35.217^{\prime} \mathrm{W}$ & $12(6)$ & $0.08(0.00-0.38)$ \\
\hline \multicolumn{4}{|l|}{ El Copé sub-transects } \\
\hline Bridge Stream (325 m) & $8^{\circ} 27.826^{\prime} \mathrm{N}, 80^{\circ} 35.474^{\prime} \mathrm{W}$ & $49(4)$ & $0.84(0.70-0.93)$ \\
\hline Carmencita's Stream (375 m) & $8^{\circ} 26.826^{\prime} \mathrm{N}, 80^{\circ} 43.474^{\prime} \mathrm{W}$ & $43(2)$ & $0.02(0.00-0.12)$ \\
\hline Car Wash Stream (435 m) & $8^{\circ} 35.826^{\prime} \mathrm{N}, 80^{\circ} 43.308^{\prime} \mathrm{W}$ & $27(6)$ & $0.00(0.00-0.13)$ \\
\hline Sofia's Stream (435 m) & $8^{\circ} 35.826^{\prime} \mathrm{N}, 80^{\circ} 43.308^{\prime} \mathrm{W}$ & $141(6)$ & $0.04(0.02-0.09)$ \\
\hline Rio Guabal Stream (680 m) & $8^{\circ} 40^{\prime} \mathrm{N}, 80^{\circ} 37.62^{\prime} \mathrm{W}$ & $151(24)$ & $0.77(0.70-0.84)$ \\
\hline Quebrada Silenciosa (700 m) & $8^{\circ} 40^{\prime} \mathrm{N}, 80^{\circ} 37.62^{\prime} \mathrm{W}$ & $142(18)$ & $0.66(0.58-0.74)$ \\
\hline Quebrada Cascada (725 m) & $8^{\circ} 40^{\prime} \mathrm{N}, 80^{\circ} 37.62^{\prime} \mathrm{W}$ & 125 (19) & $0.65(0.56-0.73)$ \\
\hline Loop Stream $(800 \mathrm{~m})$ & $8^{\circ} 40^{\prime} \mathrm{N}, 80^{\circ} 37.62^{\prime} \mathrm{W}$ & $130(18)$ & $0.72(0.64-0.80)$ \\
\hline Main Trail (800 m) & $8^{\circ} 40^{\prime} \mathrm{N}, 80^{\circ} 37.62^{\prime} \mathrm{W}$ & $80(21)$ & $0.19(0.11-0.29)$ \\
\hline Loop Trail (750 m) & $8^{\circ} 40^{\prime} \mathrm{N}, 80^{\circ} 37.62^{\prime} \mathrm{W}$ & $113(18)$ & $0.10(0.05-0.17)$ \\
\hline Sendero Verrugosa (760 m) & $8^{\circ} 40^{\prime} \mathrm{N}, 80^{\circ} 37.62^{\prime} \mathrm{W}$ & $71(17)$ & $0.28(0.18-0.40)$ \\
\hline Verrugosa Pond (780 m) & $8^{\circ} 40^{\prime} \mathrm{N}, 80^{\circ} 37.62^{\prime} \mathrm{W}$ & $8(4)$ & $0.75(0.35-0.97)$ \\
\hline
\end{tabular}


Table 4. Batrachochytrium dendrobatidis. Results of logistic regression analysis examining effects of elevation, habitat and lifetime aquatic indices (AI) on infection prevalence along the Santa Fé elevational transect, July 2004, 2 yr postdecline. Data set consisted of 186 data-points

\begin{tabular}{|lccccc|}
\hline Variable & Estimate & $\mathrm{SE}$ & $\mathrm{df}$ & $\chi^{2}$ & $\mathrm{p}$ \\
\hline Intercept & -2.0300 & 33.0640 & 1 & 0.0101 & 0.9200 \\
Elevation & - & - & 1 & 6.8416 & 0.0089 \\
$>500 \mathrm{~m}$ & 0.5744 & - & - & - & - \\
$<500 \mathrm{~m}$ & -0.5744 & - & - & - & - \\
Habitat & - & - & 2 & 6.8151 & 0.0331 \\
Terrestrial & 0.7337 & - & - & - & - \\
Pool/puddle & 0.0993 & - & - & - & - \\
Stream & -0.8330 & - & - & - & - \\
AI & - & - & 1 & 0.5141 & 0.4734 \\
Whole model & - & - & 4 & 16.2001 & 0.0028 \\
\hline
\end{tabular}

\section{Epizootic}

$B d$ was first detected at PNOT in September 2004 (Fig. 2a) and was followed by precipitous declines in amphibian density to between 0.00 and 0.05 captures $\mathrm{m}^{-1} \mathrm{p}^{-1}$ between October 2004 and January 2005. Prevalence of infection increased rapidly (repeated

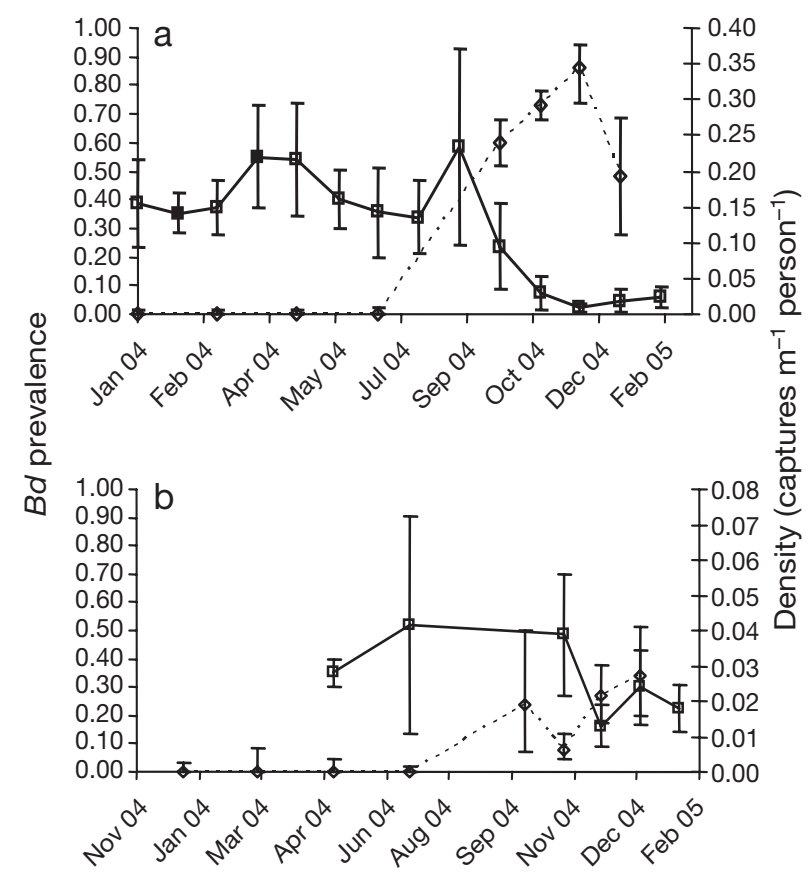

Fig. 2. Batrachochytrium dendrobatidis $(B d)$. Patterns of prevalence (dashed line) and amphibian density (solid line) during an epizootic at PNOT (January 2004 through February 2005). Error bars around density estimates are SD. Error bars around prevalence estimates are $95 \%$ confidence intervals. (a) Riparian surveys: overall amphibian density declined significantly. (b) Terrestrial surveys: the epizootic was less severe or occurred at a later date than that of streams. Statistical analyses were not possible due to uneven sampling occasions measures ANOVA, $F_{12,36}=76.46, \mathrm{p}<$ 0.0001 ) in riparian habitats within PNOT, while riparian amphibian relative abundance rapidly declined (repeated measures ANOVA, $F_{13,39}=$ 9.03, $\mathrm{p}<0.0001$ ) during the same time period (Fig. 2a), describing an epizootic pattern of disease progression. Changes in disease prevalence and amphibian density on terrestrial transects were lower than those for riparian transects (Fig. 2b) although statistical analyses were not possible because data were not collected at regular intervals.

Along the ECT, Bd infected individuals in all habitats, at all elevations, at 13 of 14 sub-transects, in 24 of 26 (92.3\%) species with sample sizes $>5$, and in 41 of $53(76.5 \%)$ of all species regardless of sample size (Table 3). Riparian species declined faster than terrestrial species (Lips et al. 2006). $B d$ was not present at lower elevation sites at the first sampling date in May 2004, but was present at all but one of these sub-transects by December 2004. $B d$ infection prevalence in riparian amphibian populations increased from 0 to $>50 \%$ within 3 mo (Fig. 2a), but this increase was less severe in terrestrial populations over the same period (Fig. 2b). Logistic regression revealed significant effects of elevation and habitat, but not $\mathrm{AI}$, on $B d$ infection prevalence (Table 5). The overall model was highly significant (Table 5) and the Hosmer and Lemeshow (2000) goodness-of-fit test was non-significant $\left(\chi^{2}=9.5117\right.$, $\mathrm{df}=5$, $\mathrm{p}=0.09$ ) indicating adequate fit of observed data to values predicted from the logistic regression model. No pair-wise interactions among habitat, elevation, or AI were detected.

$B d$ was found at all elevations, from 80 to $760 \mathrm{~m}$, although odds-ratio estimates indicated that amphibians sampled at elevations over $500 \mathrm{~m}$ were 9.1 (95\% CI $=6.4-13.0)$ times more likely to be infected than amphibians sampled below $500 \mathrm{~m}$, that amphibians encountered in riparian habitats were twice as likely to be infected with $B d$ as those captured from pool and puddle habitats (2.03, 0.75-5.50), and that amphibians captured in pool and puddles habitats were 5 times $(0.23,0.08-0.65)$ more likely to be infected than those captured from terrestrial habitats. Thus, amphibians encountered in riparian habitats were approximately 10 times more likely to be found infected than those in terrestrial habitats (Table 5).

Prevalence estimates among riparian amphibian species were generally high, ranging from 0.22 (95\% CI 0.11-0.45) in Hyalinobatrachium colymbiphyllum to 
Table 5. Batrachochytrium dendrobatidis. Results of logistic regression analysis examining effect of elevation, habitat, and lifetime aquatic indices (AI) on infection prevalence along El Copé transect during epizootic (October 2004 to January 2005). Data set consisted of 1121 data-points

\begin{tabular}{|lccccc|}
\hline Variable & Estimate & SE & df & $\chi^{2}$ & $p$ \\
\hline Intercept & -1.5590 & 0.2498 & 1 & 38.9526 & $<0.0001$ \\
Elevation & - & - & 1 & 149.1445 & $<0.0001$ \\
$>500 \mathrm{~m}$ & 1.1055 & - & - & - & - \\
$<500 \mathrm{~m}$ & -0.1055 & - & - & - & - \\
Habitat & - & - & 2 & 101.4984 & $<0.0001$ \\
Terrestrial & -1.2136 & - & - & - & - \\
Pool/puddle & 0.2529 & - & - & - & - \\
Stream & 0.9607 & - & - & - & - \\
AI & - & - & 1 & 1.0364 & 0.3086 \\
Whole model & - & - & 4 & 245.8944 & $<0.0001$ \\
\hline
\end{tabular}

\section{Epizootic stage of infection}

We found high prevalence of $B d$ in many species of amphibians across a broad range of elevations and habitats. Early reports focused on the rapid declines and die-offs of riparian amphibians at upland sites (Richards et al. 1993, Laurance et al. 1996, Lips 1998, Lips et al. 2003b, 2006), but additional studies have verified that $B d$ infects terrestrial species and amphibians at lower elevations (Bell et al. 2004, Burrowes et al. 2004, Beard \& O'Neill 2005, Lips et al. 2006, present study).

The presence of multiple biotic (e.g. tadpoles, adults of less vulnerable spe-

0.92 (0.64-0.99) in Colostethus panamensis. Bd infection prevalence was lower in terrestrial amphibians, but still high, ranging from 0.20 to 0.50 . None of the 92 individuals of $C$. panamensis sampled within PNOT at $>500 \mathrm{~m}$ prior to July 2004 was infected by $B d(0.00$, 0.64-0.99), but by December 2004 prevalence was high $(0.92,0.64-0.99)$ and populations at higher elevations had almost completely disappeared. During the December sampling period conspecific populations varied in prevalence, ranging from $0.00(0.00-0.13)$ to 0.89 (0.72-0.98). At <500 m elevation, C. panamensis was at high abundance and low or zero prevalence of $B d$ infection at both Sofia's $(0.16 \pm 0.05$ SD captures $\left.\mathrm{m}^{-1} \mathrm{p}^{-1} ; 0.04,95 \% \mathrm{CI}=0.02-0.09\right)$ and Car Wash Stream (0.075 captures $\left.\mathrm{m}^{-1} \mathrm{p}^{-1} ; 0.00,0.00-0.13\right)$, while at Bridge Stream C. panamensis abundance was similar to that of Car Wash Stream and prevalence was extremely high $\left(0.08 \pm 0.06\right.$ captures $\mathrm{m}^{-1} \mathrm{p}^{-1}$; 0.84, 0.70-0.93).

\section{DISCUSSION}

The general pattern of disease progression was similar at both sites, with initially high abundance of amphibians in all habitats followed by the arrival of $B d$ at the site and subsequent die-offs and declines in amphibian populations as $B d$ infection prevalence and disease-induced mortality increased. This supports the conclusion that $B d$ is an exotic pathogen (Skerratt et al. 2007) invading these and other naive amphibian communities (e.g. Las Tablas, Costa Rica, Lips et al. 1998; Fortuna, Panama, Lips 1999; Las Cruces, Costa Rica, Lips et al. 2003a; southern Mexico, Lips et al. 2004; Braulio Carrillo National Park, Costa Rica, Puschendorf et al. 2006) in upland areas of the Neotropics (Lips et al. 2006), and likely Australia (Laurance et al. 1996). cies) and abiotic reservoirs (e.g. moist substrates) in tropical cloudforest sites may maintain high levels of $B d$ in the environment and can facilitate transmission among remaining hosts (Haydon et al. 2002, de Castro \& Bolker 2005) and may contribute to the ability of $B d$ to cause species extinctions through density-independent pathways. Biotic reservoirs likely exist in most areas either because some hosts carry avirulent infections, or because warmer and/or drier environmental conditions reduce the pathogenicity of $B d$.

The broad host and habitat range of $B d$ likely contributes to the overall density of infected individuals, and eventually the buildup of zoospore abundance within and among individuals at a site, increasing the potential for a severe epizootic (Briggs et al. 2005). The rapid increase in prevalence of $B d$ at El Copé immediately after first detection suggests that it is highly transmissible. Transmission dynamics for $B d$ are not known, but $B d$ persists in the environment for days or weeks under natural conditions (Lips et al. 2006, M. J. Parris pers. comm.), and many species at El Copé overlap in habitat use (Witters 2000), so amphibians may become infected when they occupy any moist habitat that can support zoospores (Lips et al. 2006).

Not all species are equally affected (e.g. Lips et al. 2003b). As with all host-pathogen systems, interactions among $B d$, amphibian host species, and their environments likely determine the various patterns of infection prevalence and disease. During the epizootic, $B d$ infection prevalence increased more rapidly in riparian areas than in surrounding terrestrial areas, suggesting that pathogen transmission rates are highest in riparian areas.

Four hypotheses might explain more rapid transmission in riparian habitats. The first is that riparian amphibians occurred at higher densities, facilitating rapid density-dependent transmission (e.g. Lips et al. 2006). In this scenario, density-dependent transmission 
occurs during the early stages of an epizootic, through direct contact or by indirect transmission through the environment (Anderson \& May 1981). Once Bd becomes enzootic the density of uninfected individuals is too low to sustain $B d$ through density-dependent transmission alone, but even at low amphibian density $B d$ may continue to be transmitted through densityindependent contact such as amplexus, territorial defense, habitat preferences, and other aggregative behaviors. There was no evidence that density affected the prevalence of chytridiomycosis in an assemblage of Australian rainforest frogs where $B d$ had become enzootic (Woodhams \& Alford 2005), but this hypothesis was tested using a post-epizootic amphibian population, where pre-epizootic density was likely much higher. The second hypothesis is that the rapid transmission among riparian amphibians results from earlier arrival of $B d$ in streams as compared to terrestrial habitats, and that prevalence in terrestrial habitats lags behind that of riparian habitats. This is supported by the complete disappearance of Craugastor punctariolus (Ryan et al. 2008) and Colostethus panamensis (K. R. Lips unpubl. data), 2 obligate riparian species, within 4 mo of the arrival of $B d$ at El Copé. The third, untested hypothesis is that as a group, individuals comprising the terrestrial amphibian community are less susceptible to infection. Preliminary results show that species of El Copé amphibians vary in the number, type, and amount of antimicrobial peptides (Woodhams et al. 2006), and thus in their ability to resist or eliminate $B d$ infection. Bacteria present on the amphibian epidermis may also inhibit $B d$ through the exogenous production of antimicrobial peptides (Harris et al. 2006); if terrestrial amphibians as a group shared similar epidermal microbial fauna as an evolutionary response to similar environmental agents then they may be less susceptible as a group. Other innate immune functions of amphibians are not well known regarding protection against $B d$ infection, but phylogenetic similarities of immune function may affect infection prevalence in nature. The fourth hypothesis is that the terrestrial environment is less competent as an environmental reservoir because it is drier and warmer than riparian habitats. A related issue is that the dry season begins in December at El Copé, and that this might have reduced transmissibility or pathogenicity of $B d$ at this time. Further research is needed to determine which of these factors affect transmission in wild populations.

Temperature and moisture influence the fate of amphibian populations by affecting the rate of spread and probability of persistence of $B d$ once it is enzootic (e.g. Berger et al. 2004, Woodhams \& Alford 2005, Kriger \& Hero 2006), but it is not known what role, if any, these factors play during the epizootic stage of disease. We quantified variation in prevalence of $B d$ among populations of Colostethus panamensis across an elevational gradient, and attributed that to differences in microclimate, population connectivity, or time since invasion by $B d$. With our data we cannot distinguish between the possibility that $B d$ invaded populations at all elevations simultaneously but that less favorable growth conditions at lower elevations reduced pathogenicity and incidence of infection there, or the possibility that $B d$ first arrived at higher elevations and secondarily infected lower elevations. Additional research is needed to identify geographic patterns and modes of transmission of $B d$ and to document with greater resolution the timing and pathway of the arrival of $B d$ among elevations, habitats and species.

\section{Enzootic stage of infection}

On the SFT, $B d$ was prevalent among amphibian populations in all habitats, and at all elevations, with highest prevalence at higher elevations. Compared to the ECT, patterns of infection along the SFT were similar with regards to elevation although we had few samples from mid- and low elevations. $B d$ prevalence was generally greater at higher elevations than at lower elevations, likely a result of cooler temperatures at higher elevations (e.g. Ron 2005, Woodhams \& Alford 2005). Habitat also influenced prevalence of infection on the SFT, although the habitat with the greatest prevalence differed from that on the ECT. During the epizootic at ECT, the prevalence of $B d$ was highest in riparian areas, but because abundance of riparian amphibians along the SFT was much reduced, the pathogen load was likely much reduced. Instead, along the SFT, pool habitats had the highest abundance of amphibians and the highest prevalence of $B d$, suggesting that pond hydrology, exposure to sunlight or ultraviolet radiation, or higher and more variable water temperatures might limit growth and/or infection level of $B d$ in this amphibian community. The shift from riparian to pool habitats as the primary infection site during the course of the epizootic suggests that $B d$ requires abundant amphibian populations to sustain high levels of infection in an area, and in Central America such conditions only occur in post-epizootic pool habitats.

Species differences might also have influenced enzootic patterns of infection along the SFT. Species inhabiting pools might be less susceptible to infection because of differences in antimicrobial peptide activity (e.g. Woodhams et al. 2006), population connectivity (e.g. Robertson et al. 2008), or behavior (Rowley \& Alford 2007). Pool species tend to be generalists with broad geographic and elevational ranges, traits that 
have been associated with high mobility, and with immune systems adapted to deal with a wider range of pathogens (Altizer et al. 2003). The species Agalychnis callidryas, Rhinella marinus, Dendropsophus microcephalus, Lithobates warszewitschii, L. pipiens sp. 'E', and Smilisca phaeota, are all potential reservoirs and vectors of $B d$ (sensu Haydon et al. 2002). These species have broad elevational ranges (most encompassing 0 to $2500 \mathrm{~m}$ elevation), high dispersal capability (Savage 2002, Wells 2007), and pathogenicity of $B d$ in these species is low based on simultaneously high $B d$ infection prevalence and amphibian abundance. Dispersing individuals of these species may spread $B d$ among habitats and elevations, and will also limit recovery of more sensitive species. Alternatively, these frogs with high prevalence of $B d$ might have been recent immigrants to SFT from lowland populations, although we did not conduct mark-recapture or genetic studies to distinguish between these 2 possibilities.

\section{Overall patterns}

Differences in prevalence may be a result of differences among amphibian species (e.g. Woodhams et al. 2006), differences among strains of $B d$ (e.g. Morgan et al. 2007), environmental differences (Ron 2005), or perhaps a longer co-evolutionary history of $B d$ and amphibians among sites. For example, we noted a decrease in prevalence over time for enzootic populations with known dates of decline. In Panama, we found that the prevalence of $B d 2$ yr post-epizootic was 0.69 along the SFT, and 4 mo post-epizootic along the ECT it was 0.49 to 0.56 (Lips et al. 2006). These were higher than the 0.15 (Woodhams \& Alford 2005), 0.27 (Kriger \& Hero 2006), and 0.18 to 0.28 (Retallick et al. 2004) prevalence reported for tropical Australian amphibians with enzootic infections, all of which were sampled $\geq 8$ yr post-decline.

Our results agree with the supposition that most montane amphibians may be threatened with $B d$, that upland populations of some species persist post-decline (Retallick et al. 2004, Kriger \& Hero 2006), and that some low elevation populations may exist with high levels of infection at relatively high abundance (Kriger \& Hero 2006). Species that occur at both upland and lowland sites and for which $B d$ has low pathogenicity may function as both reservoirs and vectors, and it will be important to know the host-pathogen dynamics in these populations to better understand transmission and persistence of $B d$. Our results also confirm the broad host specificity of $B d$ (Lips et al. 2006); the generalist nature of $B d$ may enable it to greatly reduce abundance and species richness of amphibian communities through disease-induced mortality (de Castro \& Bolker 2005).
Declines attributed to $B d$ in terrestrial and pool amphibians have rarely been reported (Daszak et al. 2003, Bell et al. 2004), although $B d$ has now been reported from many countries, habitats, and elevations where population declines have either not been observed (e.g. Ouellet et al. 2005), not reported, or not attributed to $B d$ (e.g. Daszak et al. 2003, Whitfield et al. 2007).

In summary, our survey of $B d$ infection along 2 elevational transects shows that during an epizootic, prevalence is high at all elevations, in all habitats and in all species, but especially in species from $>500 \mathrm{~m}$ elevation and those inhabiting riparian habitats. Many species showed high levels of prevalence and subsequently declined by over $70 \%$ within a year of invasion by $B d$ (K. R. Lips unpubl. data); species most associated with riparian habitats had higher prevalence of $B d$ infection and suffered more severe population declines than those that were completely terrestrial. Once $B d$ becomes enzootic, prevalence declines and is highest in habitats where amphibians persist, primarily pools, puddles and terrestrial habitats. Further research is needed to understand how amphibian and pathogen ecology and evolution interact with environmental conditions to produce various levels of population response to infection by $B d$.

Acknowledgements. We thank E. Schauber, J. Reeve, R. Brenes, M. Ryan, K. Regester, J. Frazier, D. E. Green, S. Galeano, J. Robertson, C. Mott, S. Rodríguez, S. Connelly, S. Arcia, M. Takahashi, M. Venesk, M. Parris, J. Longcore, J. Collins, R. Alford, C. Carey, J. Mendelson, R. Puschendorf, M. Whiles, E. Toríbio and the Herpetology Lab groups at SIUC and Memphis for advice and assistance on various aspects of this project. Thanks to J. Wood of Pisces Molecular for genetic analyses, and to M. Doran and staff for assistance in the SIUC Histology Lab. This work was funded by the National Science Foundation (DEB 0213851, 0234386, 0130273, 9996355), and the Bay and Paul Foundation (to K.R.L).

\section{LITERATURE CITED}

Altizer SM, Harvell D, Friedle E (2003) Rapid evolutionary dynamics and disease threats to biodiversity. Trends Ecol Evol 18:589-596

Anderson RM, May RM (1981) The population-dynamics of micro-parasites and their invertebrate hosts. Proc R Soc Lond B Biol Sci 291:451-524

Anderson RM, May RM (1992) Infectious diseases of humans: dynamics and control. Oxford University Press, New York

Annis SL, Dastoor FP, Zeil H, Daszak P, Longcore JE (2004) A DNA-based assay identifies Batrachochytrium dendrobatidis in amphibians. J Wildl Dis 40:420-428

Beard KH, O'Neill EM (2005) Infection of an invasive frog Eleutherodactylus coqui by the chytrid fungus Batrachochytrium dendrobatidis in Hawaii. Biol Conserv 126:591-595

Bell BD, Carver S, Mitchell NJ, Pledger S (2004) The recent decline of a New Zealand endemic: How and why did 
populations of Archey's frog Leiopelma archeyi crash over 1996-2001. Biol Conserv 120:189-199

Berger L, Speare R, Hines HB, Marantelli G and others (2004) Effect of season and temperature on mortality in amphibians due to chytridiomycosis. Aust Vet J 82:434-439

Briggs CJ, Vredenburg VT, Knapp RA, Rachowicz LJ (2005) Investigating the population-level effects of chytridiomycosis: an emerging infectious disease of amphibians. Ecology 86:3149-3159

Burrowes PA, Joglar RL, Green DE (2004) Potential causes for amphibian declines in Puerto Rico. Herpetologica 60: 141-154

Daszak P, Cunningham AA, Hyatt AD (2000) Emerging infectious diseases of wildlife - threats to biodiversity and human health. Science 287:443-449

> Daszak P, Cunningham AA, Hyatt AD (2003) Infectious disease and amphibian population declines. Divers Distrib 9:141-150

Daszak P, Strieby A, Cunningham AA, Longcore JE, Brown CC, Porter D (2004) Experimental evidence that the bullfrog (Rana catesbeiana) is a potential carrier of chytridiomycosis, an emerging fungal pathogen of amphibians. Herpetol J 14:201-207

Davidson EW, Parris M, Collins JP, Longcore JE, Pessier AP, Brunner J (2003) Pathogenicity and transmission of chytridiomycosis in tiger salamanders. Copeia 2003: 601-607

de Castro F, Bolker B (2005) Mechanisms of disease-induced extinction. Ecol Lett 8:117-126

> Gubler DJ (1998) Resurgent vector-borne diseases as a global health problem. Emerg Infect Dis 4:442-450

Harris RN, James TY, Lauer A, Simon MA, Patel A (2006) Amphibian pathogen Batrachochytrium dendrobatidis is inhibited by the cutaneous bacteria of amphibian species. EcoHealth 3:53-56

Harvell CD, Mitchell CE, Ward JR, Altizer S, Dobson AP, Ostfeld RS, Samuel MD (2002) Climate warming and disease risks for terrestrial and marine biota. Science 296: 2158-2162

- Haydon DT, Cleaveland S, Taylor LH, Laurenson MK (2002) Identifying reservoirs of infection: a conceptual and practical challenge. Emerg Infect Dis 8:1468-1473

Holdridge LR (1967) Life zone ecology. Tropical Science Center, San José

Hosmer DW, Lemeshow S (2000) Applied logistic regression, 2nd edn. Wiley, New York

> Hyatt AD, Boyle DG, Olsen V, Boyle DB and others (2007) Diagnostic assays and sampling protocols for the detection of $\mathrm{Ba}$ trachochytrium dendrobatidis. Dis Aquat Org 73: 175-192

Kriger K, Hero JM (2006) Large-scale seasonal variation in the prevalence and severity of chytridiomycosis. J Zool (Lond) 271:352-359

Kriger KM, Hero JM (2007) The chytrid fungus Batrachochytrium dendrobatidis is non-randomly distributed across amphibian breeding habitats. Divers Distrib 13: 781-788

Laurance WF, McDonald KR, Speare R (1996) Epidemic disease and the catastrophic decline of Australian rainforest frogs. Conserv Biol 10:406-413

Lips KR (1998) Decline of a tropical montane amphibian fauna. Conserv Biol 12:106-117

Lips KR (1999) Mass mortality and population declines of anurans at an upland site in western Panama. Conserv Biol 13:117-125

Lips KR, Reaser JK, Young BE, Ibáñez R (2001) Amphibian monitoring in Latin America: a protocol manual. Soc Study Amphib Reptiles, Herpetol Circ No. 30

Lips KR, Green DE, Papendick R (2003a) Chytridiomycosis in wild frogs from southern Costa Rica. J Herpetol 37: $215-218$

Lips KR, Reeve JD, Witters LR (2003b) Ecological traits predicting amphibian population declines in Central America. Conserv Biol 17:1078-1088

Lips KR, Mendelson JR III, Muñoz Alonso A, Canseco-Marquez L, Mulcahy DG (2004) Direct evidence of declines in amphibian populations in montane southern Mexico. Biol Conserv 119:555-564

Lips KR, Brem F, Brenes R, Reeve JD and others (2006) Emerging infectious disease and the loss of biodiversity in a Neotropical amphibian community. Proc Natl Acad Sci USA 103:3165-3170

> Morehouse EA, James TY, Ganley ARD, Vilgalys R, Berger L, Murphy OJ (2003) Multilocus sequence typing suggests the chytrid pathogen of amphibians is a recently emerged clone. Mol Ecol 12:395-403

> Morgan JAT, Vredenburg V, Rachowicz LJ, Knapp RA and others (2007) Enigmatic amphibian declines and emerging infectious disease: population genetics of the frog-killing fungus Batrachochytrium dendrobatidis. Proc Natl Acad Sci USA 104:13845-13850

National Academy of Science (2001) Grand challenges in environmental biology. National Academy Press, Washington, DC

Nichols DK, Lamirande EW, Pessier AP, Longcore JE (2001) Experimental transmission of cutaneous chytridiomycosis in dendrobatid frogs. J Wildl Dis 37:1-11

Ouellet M, Mikaelian I, Paul BD, Rodrigue J, Green DM (2005) Historical evidence of widespread chytrid infection in North American amphibian populations. Conserv Biol 19:1431-1440

Pascual M, Cazelles B, Bouma MJ, Chaves LF, Koelle K (2008) Shifting patterns: malaria dynamics and rainfall variability in an African highland. Proc R Soc Lond B Biol Sci 275:123-132

> Piotrowski JS, Annis SL, Longcore JE (2004) Physiology of Batrachochytrium dendrobatidis, a chytrid pathogen of amphibians. Mycologia 96:9-15

Pounds JA, Fogden MP, Savage JM, Gorman GC (1997) Test of null models for amphibian declines on a tropical mountain. Conserv Biol 11:1307-1322

Puschendorf R, Bolaños F (2006) Detection of Batrachochytrium dendrobatidis infections in Eleutherodactylus fitzingeri: effects of stains and body parts used. J Wildl Dis 42:301-306

Puschendorf R, Bolaños F, Chaves G (2006) The amphibian chytrid fungus along an elevational gradient before the first reported declines in Costa Rica. Biol Conserv 132:136-142

Rachowicz LJ, Knapp RA, Morgan JAT, Stice MJ, Vredenburg VT, Parker JM, Briggs CJ (2006) Infectious disease as a proximate cause of amphibian mss mortality. Ecology 87:1671-1683

> Retallick RWR, McCallum H, Speare R (2004) Endemic infection of the amphibian chytrid fungus in a frog community post-decline. PLoS Biol 2:1965-1971

Richards SJ, MacDonald KR, Alford RA (1993) Declines in populations of Australia's endemic tropical rainforest frogs. Pac Conserv Biol 1:66-77

Robertson JM, Lips KR, Heist E (2008) Fine scale gene flow and individual movements among subpopulations of Centrolene prosoblepon (Anura: Centrolenidae). Rev Biol Trop 56:13-26

> Ron S (2005) Predicting the distribution of the amphibian pathogen Batrachochytrium dendrobatidis in the New World. Biotropica 37:209-221

Rowley JJL, Alford RA (2007) Behavior of Australian rainfor- 
est stream frogs may affect transmission of chytridiomycosis. Dis Aquat Org 77:1-9

Ryan MJ, Lips KR, Eichholz MW (2008) Decline and extirpation of an endangered Panamanian stream frog population (Craugastor punctariolus) due to an outbreak of chytridiomycosis. Biol Conserv 141:1636-1647

Savage JM (2002) The amphibians and reptiles of Costa Rica: a herpetofauna between two continents, between two seas. University of Chicago Press, Chicago, IL

Skerratt LF, Berger L, Speare R, Cashins S and others (2007) Spread of chytridiomycosis has caused the rapid global decline and extinction of frogs. EcoHealth 4:125-134

Sokal RR, Rohlf FJ (1995) Biometry: the principles and practice of statistics in biological research, 3rd edn. W. H. Freeman, New York

Swinton JE, Woolhouse J, Begon ME, Dobson AP and others (2002) Microparasite transmission and persistence. In: Hudson PJ, Rizzoli A, Grenfell BT, Heesterbeek JAP, Dobson A (eds) Ecology of wildlife diseases. Oxford University
Press, New York

Wells KD (2007) The ecology and behavior of amphibians. University of Chicago Press, Chicago, IL

Whitfield SM, Bell KE, Philippi T, Sasa M and others (2007) Amphibian and reptile declines over 35 years at La Selva, Costa Rica. Proc Natl Acad Sci USA 104:8352-8356

Witters LR (2000) The spatial structure and habitat associations of anurans in tropical montane streams. MSc thesis, Southern Illinois University, Carbondale, IL

Woodhams DC, Alford RA (2005) Ecology of chytridiomycosis in rainforest stream frog assemblages of tropical Queensland. Conserv Biol 19:1449-1459

Woodhams DC, Alford RA, Marantelli G (2003) Emerging disease of amphibians cured by elevating body temperature. Dis Aquat Org 55:65-67

> Woodhams DC, Voyles J, Lips KR, Carey C, Rollins-Smith LA (2006) Predicted disease susceptibility in a Panamanian amphibian assemblage based on skin peptide defenses. J Wildl Dis 42:207-218

Appendix 1. Summary of all individuals of all species assayed histologically for Batrachochytrium dendrobatidis infection from El Copé and Santa Fé elevational transects. Tissues were taken from vouchers in the Southern Illinois University Carbondale (SIUC) Wet Vertebrate Collection. Carcasses were collected from amphibian mass-mortality event at Parque Nacional Division General Omar Torríjos Herrera, Coclé, Panama. All tissues taken with permission from: SIUC Wet Vertebrate Collection and University of Michigan Museum of Vertebrate Zoology (UMMZ). University of Panama samples (UP) were assayed at SIUC before being annexed to the UP herpetological collection

\begin{tabular}{|c|c|c|c|c|c|}
\hline \multicolumn{3}{|c|}{ Site, year, deposition } & \multicolumn{3}{|c|}{ Site, year, deposition } \\
\hline Voucher no. & Genus & Species & Voucher no. & Genus & Species \\
\hline \multicolumn{3}{|c|}{ Santa Fé, 1977, UMMZ } & 167486 & Hemiphractus & fasciatus \\
\hline 147895 & Hylomantis & lemur & 167494 & Craugastor & biporcatus \\
\hline 167348 & Atelopus & varius & 167506 & Colostethus & pratti \\
\hline 167349 & Atelopus & varius & 167512 & Colostethus & pratti \\
\hline 167375 & Hylomantis & lemur & 167513 & Allobates & talamancae \\
\hline \multicolumn{3}{|c|}{ Santa Fé, 1978, UMMZ } & 167514 & Colostethus & pratti \\
\hline 155672 & Craugastor & bransfordii & 167515 & Colostethus & pratti \\
\hline 155673 & Craugastor & bransfordii & 167518 & Lithobates & warszewitschii \\
\hline 155674 & Craugastor & bransfordii & 167519 & Craugastor & gollmeri \\
\hline 155678 & Craugastor & gollmeri & 167523 & Rhinella & margaratifera \\
\hline 155680 & Craugastor & bransfordii & 167554 & Craugastor & bransfordii \\
\hline 155681 & Craugastor & bransfordii & 167555 & Craugastor & bransfordii \\
\hline 155682 & Pristimantis & caryophyllaceus & 167556 & Craugastor & bransfordii \\
\hline 155685 & Craugastor & punctariolus & 167557 & Craugastor & bransfordii \\
\hline 155686 & Pristimantis & caryophyllaceus & 167561 & Craugastor & bransfordii \\
\hline 167315 & Lithobates & pipiens sp. ' $E^{\prime}$ & 167574 & Pristimantis & caryophyllaceus \\
\hline 167316 & Lithobates & pipiens sp. ' $E^{\prime}$ & 167575 & Hyalinobatrachium & valerioi \\
\hline 167317 & Lithobates & pipiens sp. ' $E$ ' & 167581 & Lithobates & pipiens sp. ' $E$ ' \\
\hline 167318 & Lithobates & pipiens sp. ' $E$ ' & 167590 & Smilisca & phaeota \\
\hline 167319 & Lithobates & pipiens sp. ' $E$ ' & 167612 & Craugastor & podiciferus \\
\hline 167320 & Lithobates & pipiens sp. ' $E$ ' & 167613 & Craugastor & bransfordii \\
\hline 167325 & Craugastor & punctariolus & 167614 & Craugastor & bransfordii \\
\hline 167340 & Lithobates & pipiens sp. ' $E$ ' & 167615 & Craugastor & bransfordii \\
\hline 167364 & Lithobates & pipiens sp. ' $E^{\prime}$ & 167622 & Pristimantis & cruentus \\
\hline 167382 & Dendrobates & auratus & 167623 & Craugastor & talamancae \\
\hline 167424 & Hyalinobatrachium & valerioi & 167624 & Pristimantis & diastema \\
\hline 167427 & Hyalinobatrachium & valerioi & 167649 & Craugastor & talamancae \\
\hline 167430 & Lithobates & pipiens sp. ' $E^{\prime}$ & 167650 & Pristimantis & cerasinus \\
\hline 167431 & Lithobates & pipiens sp. ' $E$ ' & 167665 & Eleutherodactylus & sp. \\
\hline 167432 & Lithobates & pipiens sp. ' $E$ ' & 168281 & Craugastor & bransfordii \\
\hline 167435 & Lithobates & pipiens sp. 'E' & \multicolumn{3}{|c|}{ Santa Fé, 2002, SIUC } \\
\hline 167444 & Lithobates & pipiens sp. ' $E$ ' & H06999 & Lithobates & warszewitschii \\
\hline 167460 & Colostethus & pratti & H07019 & Cochranella & spinosa \\
\hline 167485 & Hemiphractus & fasciatus & $\mathrm{H} 07026$ & Centrolene & prosoblepon \\
\hline
\end{tabular}


Appendix 1 (continued)

\begin{tabular}{|c|c|c|c|c|c|}
\hline \multicolumn{3}{|c|}{ Site, year, deposition } & \multicolumn{3}{|c|}{ Site, year, deposition } \\
\hline Voucher no. & Genus & Species & Voucher no. & Genus & Species \\
\hline H07032 & Craugastor & punctariolus & H07655 & Silverstonei & flotator \\
\hline H07033 & Craugastor & punctariolus & H07656 & Colostethus & panamensis \\
\hline H07041 & Pristimantis & museosus & H07657 & Silverstonei & flotator \\
\hline H07048 & Pristimantis & museosus & H07658 & Colostethus & pratti \\
\hline H07050 & Cochranella & albomaculata & H07659 & Colostethus & pratti \\
\hline H07055 & Pristimantis & cruentus & H07660 & Silverstonei & nubicola \\
\hline H07057 & Gastrotheca & cornuta & H07662 & Colostethus & panamensis \\
\hline H07058 & Eleutherodactylus & n. sp. & H07663 & Silverstonei & nubicola \\
\hline H07060 & Strabomantis & bufoniformis & H07664 & Silverstonei & flotator \\
\hline \multicolumn{3}{|c|}{ Santa Fé, 2003, SIUC } & H07665 & Silverstonei & nubicola \\
\hline \multirow[t]{2}{*}{ H07286 } & Centrolene & prosoblepon & H07666 & Colostethus & panamensis \\
\hline & Colostethus & panamensis & H07667 & Colostethus & pratti \\
\hline H07661 & Silverstonei & nubicola & H07668 & Colostethus & panamensis \\
\hline H07752 & Silverstonei & nubicola & H07669 & Cruziohyla & calcarifer \\
\hline H07290 & Craugastor & crassidigitus & H07670 & Pristimantis & diastema \\
\hline H07293 & Pristimantis & museosus & H07671 & Hyloscirtus & palmeri \\
\hline H07291 & Craugastor & noblei & $\mathrm{H} 07672$ & Pleurodema & brachyops \\
\hline H07282 & Ecnomiohyla & miliaria & H07673 & Craugastor & cf. podiciferus \\
\hline H07283 & Hyloscirtus & palmeri & H07675 & Hypsiboas & rufitelus \\
\hline H07284 & Hyloscirtus & palmeri & H07676 & Gastrotheca & cornuta \\
\hline H07285 & Hyloscirtus & palmeri & H07677 & Cruziohyla & calcarifer \\
\hline H07683 & Hyloscirtus & palmeri & H07678 & Pristimantis & caryophyllaceus \\
\hline H07706 & Hyloscirtus & palmeri & H07679 & Craugastor & bransfordii \\
\hline H07750 & Hyloscirtus & palmeri & H07680 & Craugastor & punctariolus \\
\hline H07751 & Hyloscirtus & palmeri & H07681 & Craugastor & megacephalus \\
\hline H07760 & Hyloscirtus & palmeri & H07682 & Craugastor & cf. podiciferus \\
\hline H07292 & Leptodactylus & mystacinus & H07684 & Pristimantis & cruentus \\
\hline H07287 & Lithobates & warszewitschii & H07685 & Hyloscirtus & colymba \\
\hline H07288 & Lithobates & warszewitschii & H07686 & Craugastor & talamancae \\
\hline H07289 & Lithobates & warszewitschii & H07687 & Centrolene & prosoblepon \\
\hline $\mathrm{H} 07674$ & Lithobates & warszewitschii & H07688 & Hyalinobatrachium & colymbiphyllum \\
\hline \multirow{2}{*}{ H07749 } & Lithobates & warszewitschii & H07689 & Hyalinobatrachium & colymbiphyllum \\
\hline & Lithobates & warszewitschii & H07690 & Hyalinobatrachium & colymbiphyllum \\
\hline \multicolumn{3}{|c|}{ El Copé, 2000, SIUC } & H07691 & Ollotis & conifera \\
\hline $\mathrm{H}-06927$ & Silverstonei & flotator & H07693 & Pristimantis & gaigei \\
\hline H-06928 & Colostethus & panamensis & H07694 & Pristimantis & cruentus \\
\hline H-06929 & Colostethus & panamensis & H07695 & Pristimantis & ridens \\
\hline $\mathrm{H}-06930$ & Colostethus & panamensis & H07696 & Pristimantis & ridens \\
\hline H-06931 & Colostethus & panamensis & H07697 & Pristimantis & cruentus \\
\hline H-06932 & Colostethus & panamensis & H07698 & Pristimantis & cruentus \\
\hline $\mathrm{H}-06934$ & Colostethus & panamensis & H07699 & Craugastor & punctariolus \\
\hline H-06933 & Silverstonei & nubicola & H07700 & Leptodactylus & mystacinus \\
\hline H-06935 & Silverstonei & nubicola & H07701 & Cochranella & euknemos \\
\hline H-06936 & Silverstonei & nubicola & H07702 & Craugastor & talamancae \\
\hline \multicolumn{3}{|c|}{ El Copé, 2002, SIUC } & H07703 & Craugastor & crassidigitus \\
\hline H07002 & Silverstonei & flotator & H07704 & Pristimantis & caryophyllaceus \\
\hline H07005 & Silverstonei & flotator & H07705 & Pristimantis & ridens \\
\hline H07029 & Silverstonei & flotator & $\mathrm{H} 07707$ & Hyalinobatrachium & chirripoi \\
\hline H07219 & Colostethus & panamensis & H07708 & Centrolene & ilex \\
\hline H07230 & Colostethus & panamensis & H07709 & Rhaebo & haematiticus \\
\hline H07065 & Silverstonei & nubicola & H07710 & Pristimantis & pardalis \\
\hline H07078 & Silverstonei & nubicola & H07711 & Craugastor & crassidigitus \\
\hline H07081 & Colostethus & pratti & H07712 & Craugastor & gollmeri \\
\hline H07222 & Colostethus & pratti & H07713 & Pristimantis & museosus \\
\hline H07223 & Colostethus & pratti & H07714 & Strabomantis & bufoniformis \\
\hline H07220 & Colostethus & talamancae & H07715 & Craugastor & punctariolus \\
\hline \multicolumn{3}{|c|}{ El Copé, 2003, SIUC } & H07716 & Pristimantis & gaigei \\
\hline H07652 & Silverstonei & nubicola & H07717 & Smilisca & phaeota \\
\hline H07653 & Silverstonei & nubicola & H07718 & Engystomops & pustulosus \\
\hline H07654 & Colostethus & pratti & H07719 & Engystomops & pustulosus \\
\hline
\end{tabular}


Appendix 1 (continued)

\begin{tabular}{|c|c|c|c|c|c|}
\hline \multicolumn{3}{|c|}{ Site, year, deposition } & \multicolumn{3}{|c|}{ Site, year, deposition } \\
\hline Voucher no. & Genus & Species & Voucher no. & Genus & Species \\
\hline H07720 & Leptodactylus & mystacinus & UPanama & Centrolene & ilex \\
\hline H07721 & Craugastor & punctariolus & UPanama & Centrolene & prosoblepon \\
\hline H07722 & Craugastor & punctariolus & UPanama & Cochranella & albomaculata \\
\hline H07723 & Centrolene & prosoblepon & UPanama & Cochranella & euknemos \\
\hline H07730 & Centrolene & prosoblepon & UPanama & Craugastor & bransfordii \\
\hline H07732 & Pristimantis & caryophyllaceus & UPanama & Strabomantis & bufoniformis \\
\hline H07733 & Pristimantis & caryophyllaceus & UPanama & Pristimantis & caryophyllaceus \\
\hline H07734 & Pristimantis & diastema & UPanama & Craugastor & crassidigitus \\
\hline H07735 & Pristimantis & diastema & UPanama & Pristimantis & cruentus \\
\hline H07736 & Pristimantis & vocator & UPanama & Pristimantis & diastema \\
\hline H07737 & Rhaebo & haematiticus & UPanama & Pristimantis & diastema \\
\hline H07738 & Strabomantis & bufoniformis & UPanama & Pristimantis & gaigei \\
\hline H07739 & Craugastor & gollmeri & UPanama & Craugastor & gollmeri \\
\hline $\mathrm{H} 07740$ & Smilisca & phaeota & UPanama & Craugastor & megacephalus \\
\hline H07741 & Engystomops & pustulosus & UPanama & Pristimantis & museosus \\
\hline $\mathrm{H} 07742$ & Hylomantis & lemur & UPanama & Pristimantis & pardalis \\
\hline H07743 & Cochranella & albomaculata & UPanama & Craugastor & cf. podiciferus \\
\hline H07744 & Craugastor & cf. podiciferus & UPanama & Craugastor & punctariolus \\
\hline H07745 & Cochranella & euknemos & UPanama & Pristimantis & ridens \\
\hline H07746 & Pristimantis & museosus & UPanama & Craugastor & talamancae \\
\hline H07747 & Ollotis & conifera & UPanama & Pristimantis & vocator \\
\hline H07748 & Hylomantis & lemur & UPanama & Hyalinobatrachium & colymbiphyllum \\
\hline H07753 & Hyloscirtus & palmeri & UPanama & Hyloscirtus & palmeri \\
\hline H07754 & Hyloscirtus & palmeri & UPanama & Leptodactylus & mystacinus \\
\hline H07755 & Hylomantis & lemur & UPanama & Leptodactylus & savagei \\
\hline H07756 & Cochranella & albomaculata & UPanama & Hylomantis & lemur \\
\hline H07758 & Strabomantis & bufoniformis & UPanama & Engystomops & pustulosus \\
\hline H07759 & Rhaebo & haematiticus & UPanama & Pleurodema & brachyops \\
\hline UPanama & Agalychnis & callidryas & UPanama & Lithobates & warszewitschii \\
\hline UPanama & Ollotis & conifera & UPanama & Smilisca & phaeota \\
\hline UPanama & Rhaebo & haematiticus & & & \\
\hline
\end{tabular}

Editorial responsibility: Alex Hyatt, Geelong, Victoria, Australia
Submitted: March 4, 2008; Accepted: June 26, 2008

Proofs received from author(s): September 3, 2008 